\title{
Status GAKY, anemia, EYU, dan kesegaran jasmani anak sekolah dasar di Kabupaten Dairi, Sumatra Utara
}

\author{
Joner Lumban Toruan'1, B.M. Wara Kushartanti², Untung S. Widodo ${ }^{3}$
}

\begin{abstract}
Background: lodine deficiency disorder (IDD) and anemia are major health problems in Indonesia. Prevalence of TGR according to the result of IDD survey 2003 in District of Dairi is 33,9\%. Prevalence of anemia according to Household Health Survey 2001 is $47 \%$ for children of $0-5$ years old; $26.5 \%$ for school children; and $40 \%$ for eligible women. The result of a survey in Jakarta capital city special territory 2004 shows that prevalence of anemia is $26.5 \%$ for children under five and $43.5 \%$ for pregnant mothers. Thyroid hormone regulates metabolism and plays an important role in calorie production, whereas haemoglobin in the blood may distort metabolism of energy in the muscles leading to fatique.

Objective: The objective of the study was to identify the relationship between IDD, anemia, and physical fitness and to assess differences in physical fitness according to endemic level.

Method: The study was observational with cross sectional design. Location of the study was District of Dairi, Sumatra Utara. Palpation was used to identify endemic level. Three elementary schools were chosen according to endemic level. Number of samples per district and elementary school was determined using quota, and samples were selected from grade 4-6 using systematic random sampling technique. Data analysis used univariable, bivariable, and multivariable techniques. Chi square $\left(\chi^{2}\right)$ was used to identify the relationship between independent variable and dependent variable, and ANOVA test ( $F$ test) was used to find out differences in physical fitness based on endemic level.

Results: The result of statistical test showed that the relationship between IDD and physical fitness was $p=0.675$ with OR 0.8 (95\% Cl: 0.499-1.498). The relationship between anemia and physical fitness was $p=0.003$ with OR 2.29 (95\% Cl: 1.33-3.95). There were differences in physical fitness according to endemic level with $p<0.001$.

Conclusion: There was no relationship between IDD and physical fitness, but there was relationship between anemia and physical fitness and there was difference in physical fitness according to endemic level.
\end{abstract}

KEY WORDS iodine deficiency disorder, anemia, physical fitness

\section{PENDAHULUAN}

GAKY (gangguan akibat kekurangan yodium) merupakan sekumpulan gejala klinis yang timbul karena tubuh kekurangan yodium secara terus-menerus dalam jangka panjang. Anemia menunjuk pada kadar hemoglobin darah yang kurang daripada kadar normal, yang dalam penelitian ini ditentukan $12 \mathrm{mg} / \mathrm{dL}$. Anemia ditandai dengan gejala lemah, letih, lesu, pucat, nafas pendek, lidah licin, frekuensi denyut jantung meningkat, pusing, dan mudah mengantuk. EYU (ekskresi yodium urin) merupakan jumlah yodium yang diekskresi oleh urin dan digunakan untuk menggambarkan kecukupan konsumsi yodium selama sehari. Kesegaran jasmani menunjuk pada kemampuan tubuh untuk melakukan jalan atau lari dalam waktu 6 menit.

Kabupaten Dairi merupakan daerah pegunungan dengan 14 kecamatan yang dinyatakan sebagai satu-satunya kabupaten endemis berat GAKY di Provinsi Sumatra Utara menurut penelitian tahun 2003. Prevalensi TGR (total goiter rate) di Kabupaten Dairi sebesar $33,9 \%$, jauh di atas angka TGR Sumatra Utara $(5,3 \%)$ dan TGR nasional $(11,1 \%)(1)$. Berbagai program telah diluncurkan untuk mengatasi keadaan tersebut, namun belum ada evaluasi ulang yang dapat menggambarkan kondisi GAKY di Kabupaten Dairi saat ini.

Secara teoretis, GAKY berhubungan erat dengan anemia, EYU, dan kesegaran jasmani, sehingga penelitian ini bertujuan untuk menggambarkan GAKY beserta keadaan yang erat berhubungan dengannya pada anak sekolah dasar (SD).

\section{BAHAN DAN METODE}

Penelitian ini merupakan penelitian observasional dengan rancangan cross sectional yang dilakukan selama 3 bulan mulai bulan September sampai dengan bulan November 2006 pada anak SD di Kabupaten Dairi Provinsi Sumatra Utara. Sampel anak SD kelas 4-6 dipilih di daerah tersebut berdasarkan kriteria inklusi, yaitu anak tersebut sudah berada di daerah penelitian lebih dari 6 bulan dan bersedia menjadi subjek penelitian. Anak yang terdaftar sebagai atlet atau sedang sakit atau cacat fisik dieksklusi dari penelitian ini.

Cara penentuan sampel dilakukan melalui 2 tahap, diawali dengan melakukan resurvei GAKY (metode palpasi) pada 4 kecamatan. Kecamatan dipilih secara purposif dengan kriteria prevalensi tertinggi pada hasil survei tahun 1998 yang dinyatakan sebagai kecamatan endemis berat, sedang, ringan,

\footnotetext{
1 Dinas Kesehatan Kota Binjai, Jl. Gatot Subroto No. 191 Kota Binjai, Sumatra Utara

2 Fakultas IImu Keolahragaan UNY, Jl. Kolombo Baru, Yogyakarta, email:warakushartanti@yahoo.com

3 BP GAKY Magelang, Kavling Jayen Borobudur, Magelang, Jawa Tengah
} 
dan nonendemis. Jumlah SD sebagai unit analisis dipilih secara acak sebesar $30 \%$ setiap kecamatan dan palpasi dilakukan pada anak kelas 4, 5, dan 6 . Tahap kedua dilakukan dengan memilih 3 SD di setiap kecamatan menurut tingkat endemisitasnya. Dipilih satu SD dekat kecamatan, satu SD pertengahan, dan satu SD yang jauh dari kecamatan. Dengan menggunakan rumus pendugaan proporsi populasi untuk satu sampel menggunakan nilai baku distribusi normal (Z) 1,96 pada tingkat kepercayaan ( $\alpha$ ) $95 \%$, proporsi TGR anak SD (P) 33,9\%, dan presisi (d) 0,06 didapatkan jumlah sampel sebanyak 240 anak (2).

Data karakteristik responden dikumpulkan dengan angket dan wawancara, sedangkan data pembesaran kelenjar gondok dikumpulkan dengan cara palpasi oleh palpator yang telah terekomendasi. Kadar hemoglobin darah diperiksa dengan metode cyanmethemoglobin di laboratorium RSUD Sidikalang. Kadar hemoglobin $\geq 12,0 \mathrm{mg} / \mathrm{dL}$ dikategorikan sebagai tidak anemia, sedangkan kadar hemoglobin $<12,0 \mathrm{mg} / \mathrm{dL}$ sebagai anemia. Data kesegaran jasmani disidik dengan 3 macam tes, yaitu: jalan atau lari selama 6 menit, lompat-tegak, dan frekuensi push-up dalam waktu 60 detik. Setelah nilai frekuensi dari masing-masing jenis tes dijumlahkan, dirujuk dalam derajat kategori yaitu baik dan kurang. Kesegaran jasmani responden termasuk kategori baik apabila skor > 1.010 dan termasuk kategori kurang apabila skor $<1.010$. (3). Data yang telah terkumpul dianalisis secara deskriptif dan inferensial dengan program SPSS 12.0. Hubungan antarvariabel diuji dengan chi square $\left(\chi^{2}\right)$, sedangkan perbedaan kesegaran jasmani berdasarkan tingkat endemisitas dan jenis kelamin diuji dengan ANOVA.

\section{HASIL DAN BAHASAN}

\section{Prevalensi TGR}

Kecamatan yang terpilih sebagai lokasi penelitian adalah Kecamatan Parbuluan (endemis berat), Kecamatan
Silimapungga-pungga (endemis sedang), Kecamatan Sidikalang (endemis ringan), dan Kecamatan Silahi Sabungan (nonendemis). Dalam rangka skrining, dilakukan palpasi pada anak kelas 4, 5, dan 6 pada 30\% SD yang dipilih secara acak setiap kecamatan. Dari 2.184 anak yang dipalpasi, didapatkan $18,4 \%$ anak menderita gondok grade 1 dan $0,96 \%$ menderita gondok grade 2, sehingga TGR Kabupaten Dairi sebesar 19,37\%. Menurut kriteria WHO, Kabupaten Dairi termasuk daerah endemis ringan (TGR 5,019,9\%). TGR tahun 2006 yang dibandingkan dengan hasil pemetaan GAKY tahun 1998 menunjukkan ada perbedaan tingkat endemisitas pada 3 kecamatan, yaitu Sidikalang dari endemis sedang berubah menjadi endemis ringan, Silimapungga-pungga berubah dari endemis ringan menjadi endemis sedang, Silahi Sabungan berubah dari endemis ringan menjadi nonendemis. Perubahan lebih rinci untuk setiap kecamatan dapat dilihat pada Gambar 1.

Dengan perubahan tersebut, dapat disimpulkan bahwa secara umum usaha penanggulangan GAKY di Kabupaten Dairi cukup berhasil, kecuali di Parbuluan yang tetap merupakan daerah endemis berat. Hasil pemeriksaan garam beryodium yang dilakukan peneliti pada garam yang dibawa murid menggunakan iodium test kit menunjukkan kandungan yodium yang cukup. Kandungan yodium 30-40 ppm pada garam di rumah dianggap cukup untuk memenuhi kebutuhan dan kecukupan yodium sehari-hari. Hasil ini diperkuat oleh hasil survei yang dilakukan Dinas Kesehatan Sumatra Utara tahun 2003 yang menunjukkan bahwa $100 \%$ garam yang beredar di Kabupaten Dairi sudah mengandung yodium (4). Melalui perluasan cakupan program GAKY, yaitu distribusi kapsul yodium dan KIE (komunikasi, informasi, edukasi) diharapkan TGR kurang dari 5\% atau adanya perubahan dari status endemis ringan menjadi nonendemis pada tahun 2010.

Selanjutnya dipilih 247 anak menjadi sampel yang dibagi berdasarkan tingkat endemisitas. Di antara sejumlah sampel

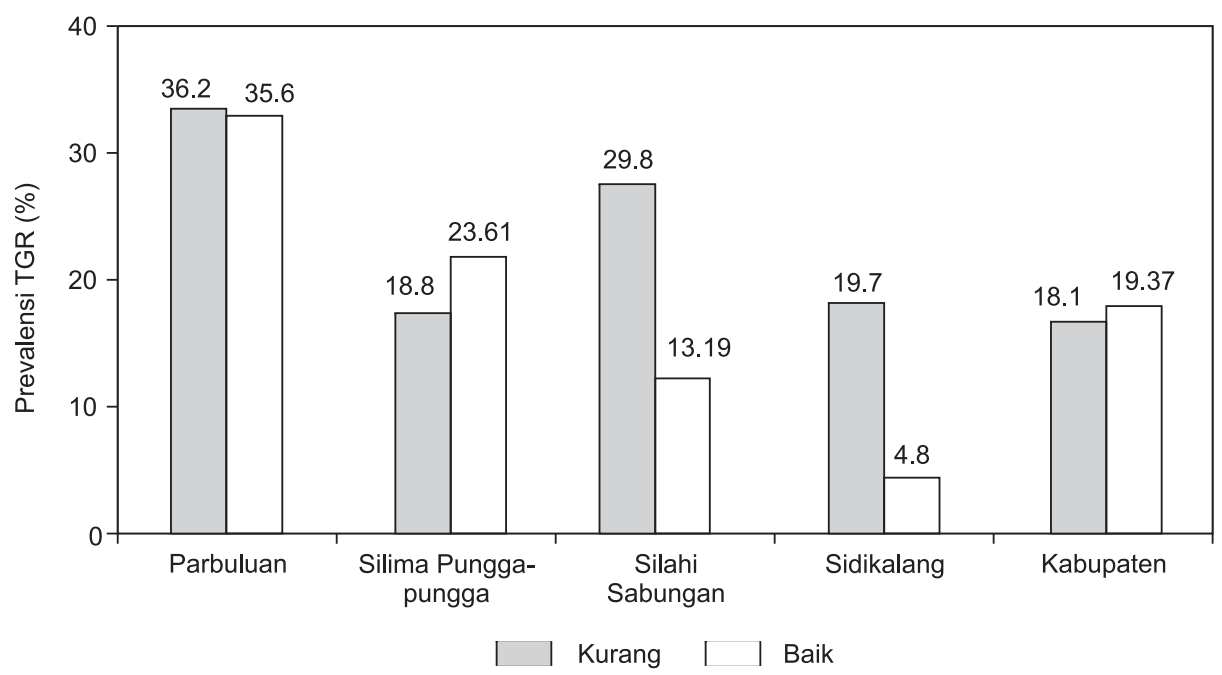

GAMBAR 1. Perubahan total goiter rate (TGR) Kabupaten Dairi tahun 1998 dan 2006 
tersebut, ada $61(24,7 \%)$ anak yang termasuk ke dalam grade 1; sebanyak $11(4,5 \%)$ anak termasuk ke dalam grade 2; dan sisanya $(70,8 \%)$ termasuk ke dalam grade 0 .

\section{Kesegaran jasmani menurut endemisitas}

Sebaran kesegaran jasmani menurut endemisitas dapat dilihat pada Gambar 2 berikut. Status kesegaran jasmani dibagi dalam dua kategori, yaitu baik dan kurang. Dari gambar tersebut terlihat hanya sedikit perbedaan antara status kesegaran jasmani dengan kategori baik dengan yang berkategori kurang. Status kesegaran jasmani yang baik pada daerah nonendemis, endemis ringan, dan endemis sedang berturut-turut ditemukan pada $35(28,5 \%)$ anak, $34(27,6 \%)$ anak, dan $32(26,0 \%)$ anak; sedangkan status kesegaran jasmani kurang berturut-turut ditemukan pada 27 (21,8\%) anak, 26 (21,0\%) anak, dan 30 $(24,2 \%)$ anak. Namun demikian, terjadi perbedaan yang mencolok antara status kesegaran jasmani baik dan kurang di daerah endemis berat, masing-masing sebesar $22(17,9 \%)$ anak dan $41(33,1 \%)$ anak.

Hal ini dibuktikan dengan hasil uji statistik ANOVA yang menunjukkan ada perbedaan signifikan rata-rata kesegaran jasmani berdasarkan endemisitas $(p<0,05)$. Analisis lanjutan menggunakan Duncan menunjukkan bahwa daerah yang paling berbeda tersebut adalah daerah endemis ringan, sedangkan daerah dengan tingkat endemis lain (nonendemis, endemis sedang, dan endemis berat) menunjukkan tidak ada perbedaan. Hairy (5) berpendapat bahwa intensitas latihan akan memberikan pengaruh yang lebih besar terhadap kesegaran jasmani. Besarnya peningkatan kesegaran jasmani tergantung kepada intensitas dan durasi latihan.

\section{Kesegaran jasmani berdasarkan jenis kelamin}

Sebaran kesegaran jasmani anak SD dari 247 anak berdasarkan jenis kelamin dapat dilihat pada Tabel 1. Dari 247 anak tersebut, 125 di antaranya adalah perempuan dan 122 anak adalah laki-laki. Kesegaran jasmani menurut jenis kelamin pada penelitian ini dibagi dalam dua kategori, yaitu baik bila nilai kesegaran jasmani anak SD >1.010 dan kurang bila nilai kesegaran jasmani anak SD $<1.010$.

Berdasarkan tabel tersebut, diketahui ada perbedaan kesegaran jasmani antara anak laki-laki dengan anak perempuan. Pada kategori kurang, anak perempuan mempunyai kesegaran jasmani lebih tinggi $(58,1 \%)$ dibanding dengan kesegaran jasmani anak laki-laki (41,9\%). Hasil uji statistik ANOVA menunjukkan ada perbedaan kesegaran jasmani yang bermakna antara sampel laki-laki dengan perempuan $(p<0,05)$. Penelitian Westcott $(6)$ membuktikan bahwa kekuatan anak laki-laki lebih unggul daripada anak perempuan walaupun latihan yang dilakukan sama. Hal ini disebabkan laki-laki memiliki ukuran otot lebih besar daripada perempuan. Kartini et al. (7) juga melaporkan bahwa ada rata-rata skor kesegaran jasmani murid laki-laki lebih tinggi dibanding murid perempuan dan perbedaan tersebut bermakna $(p<0,05)$. Menurut Rosmalina (8), tingkat

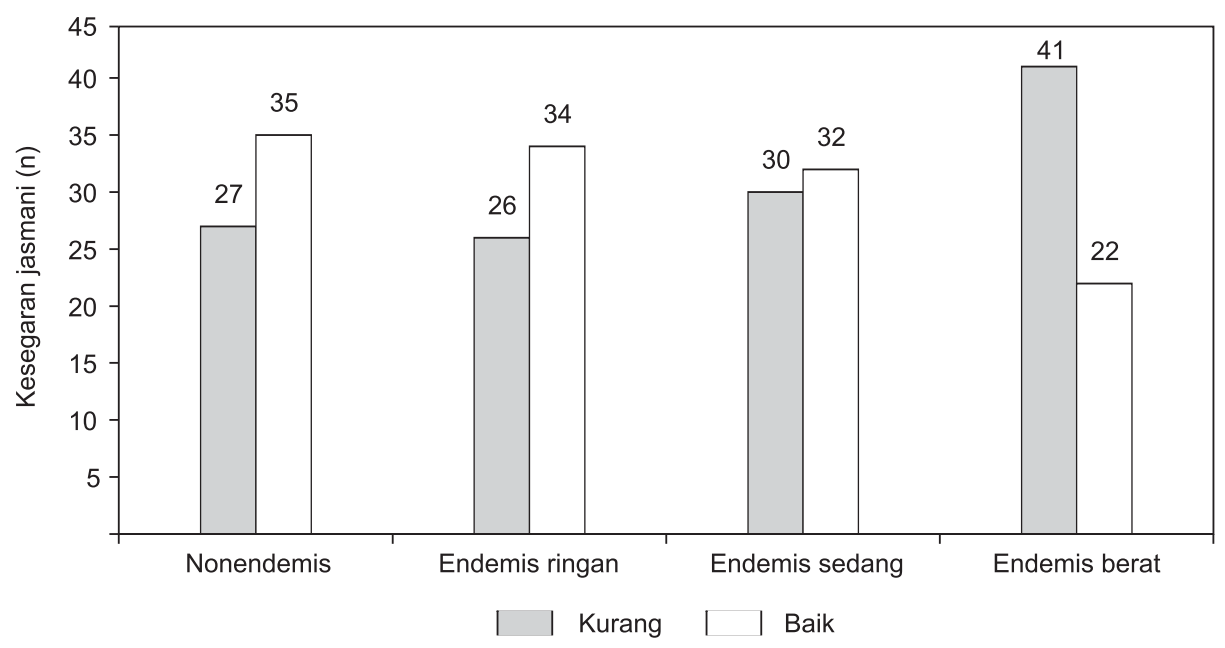

GAMBAR 2. Distribusi kesegaran jasmani berdasarkan endemisitas

TABEL 1. Kesegaran jasmani berdasarkan jenis kelamin

\begin{tabular}{|c|c|c|c|c|}
\hline \multirow{2}{*}{ Jenis kelamin } & \multicolumn{2}{|c|}{ Kesegaran jasmani } & \multirow{2}{*}{ Total } & \multirow[b]{2}{*}{ p } \\
\hline & Baik & Kurang & & \\
\hline Laki-laki & $70(56,9 \%)$ & $52(41,9 \%)$ & $122(49,4 \%)$ & $0,019^{*}$ \\
\hline Perempuan & $53(43,1 \%)$ & $72(58,1 \%)$ & $125(50,6 \%)$ & \\
\hline Total & $123(100 \%)$ & 124 (100\%) & $147(100 \%)$ & \\
\hline
\end{tabular}

Keterangan:

* Bermakna ( $p<0,05$; uji ANOVA) 
kesegaran jasmani dipengaruhi oleh banyak faktor, antara lain gaya hidup yang meliputi konsumsi makanan, pola aktivitas, dan kebiasaan merokok.

\section{Status anemia menurut endemisitas}

Status anemia berdasarkan tingkat endemisitas memberikan kenyataan yang paradoksal karena status anemia paling tinggi justru didapatkan pada daerah nonendemis $(29,7 \%)$ dan endemis ringan $(29,7 \%)$, sedangkan status tidak anemia paling tinggi $(40,2 \%)$ terdapat pada daerah endemis berat (Gambar 3). pengaruh status anemia terhadap kesegaran jasmani. Viteri dan Torun (11) juga meneliti para pemotong tebu di Guatamala yang hasilnya menunjukkan kemampuan kerja fisik bervariasi menurut kadar hemoglobin. Apabila kadar hemoglobin rendah maka skor rendah dan apabila kadar hemoglobin tinggi maka skor juga tinggi.

\section{Hubungan antara GAKY dengan kesegaran jasmani}

Hubungan antara GAKY dengan kesegaran jasmani dapat dilihat pada Tabel 3. Hasil penelitian ini menunjukkan bahwa anak yang berstatus gondok, sebagian besar

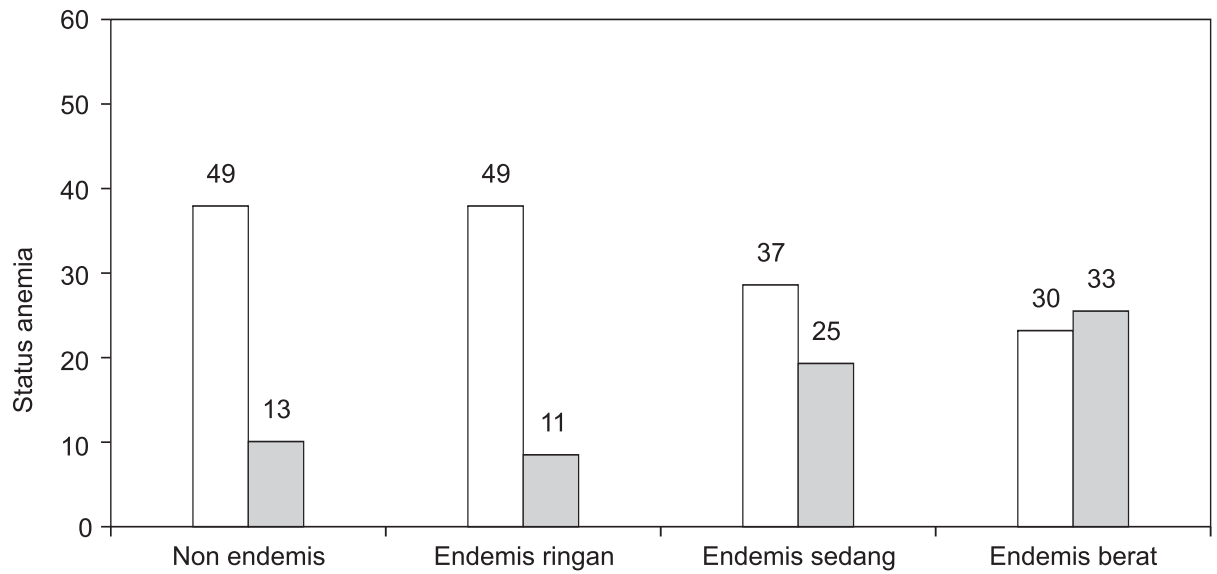

GAMBAR 3. Distribusi status anemia berdasarkan endemisitas

\section{Hubungan antara anemia dengan kesegaran jasmani}

Hubungan antara anemia dengan kesegaran jasmani terlihat pada Tabel 2 berikut ini. Dari tabel tersebut dapat dijelaskan bahwa anak dengan status anemia berpeluang mempunyai kesegaran jasmani kurang sebesar $57,0 \%$, sedangkan yang tidak anemia hanya berpeluang mempunyai kesegaran jasmani kurang sebesar 36,6\%. Hasil uji statistik menunjukkan adanya hubungan bermakna antara status anemia dengan kesegaran jasmani $(p<0,05)$. Anak yang anemia mempunyai peluang 2,29 kali mempunyai kesegaran jasmani kurang dibandingkan dengan anak yang tidak anemia. Penelitian mengenai suplementasi besi mingguan pada anak remaja putri anemia di SLTP 14 Semarang terbukti mampu meningkatkan kadar hemoglobin dan indeks kesegaran jasmani (9). Susanto et al. (10) telah melakukan penelitian di Semarang dan hasilnya menunjukkan ada memiliki kesegaran jasmani kurang, yaitu sebanyak 38 $(52,8 \%)$ anak; sedangkan anak yang berstatus tidak gondok, sebagian besar memiliki status kesegaran jasmani baik, yaitu sebanyak $89(50,2 \%)$ anak. Hasil uji statistik membuktikan tidak ada perbedaan proporsi kesegaran jasmani antara anak yang berstatus gondok dengan tidak gondok ( $p>0,05)$. Hal ini mungkin disebabkan Kabupaten Dairi merupakan daerah pertanian dan pegunungan yang berpengaruh terhadap mata pencaharian kepala keluarga yang sebagian besar adalah petani. Anak-anak selalu dituntut untuk membantu orang tua sebelum dan sesudah sekolah, antara lain: membawa pupuk, alat-alat pertanian, dan lain sebagainya untuk keperluan di kebun. Ditambah lagi dengan jarak antar sekolah dan rumah yang relatif jauh. Kegiatan tersebut tentu saja mempengaruhi ketahanan fisik anak-anak, sehingga GAKY tetap tidak berpengaruh terhadap ketahanan fisiknya.

TABEL 2. Distribusi status anemia dengan kesegaran jasmani

\begin{tabular}{|c|c|c|c|c|c|c|}
\hline \multirow{2}{*}{ Status Anemia } & \multicolumn{2}{|c|}{ Kesegaran jasmani } & \multirow{2}{*}{ Total } & \multirow{2}{*}{$\chi^{2}$} & \multirow[b]{2}{*}{ p } & \multirow{2}{*}{$\begin{array}{c}\text { OR } \\
\text { (IK 95\%) }\end{array}$} \\
\hline & Baik & Kurang & & & & \\
\hline $\begin{array}{l}\text { Anemia } \\
\text { Tidak anemia } \\
\text { Total }\end{array}$ & $\begin{array}{c}71(43,0 \%) \\
52(63,4 \%) \\
123(49,8 \%)\end{array}$ & $\begin{array}{c}94(57,0 \%) \\
30(36,6 \%) \\
124(50,2 \%)\end{array}$ & $\begin{array}{c}165(100 \%) \\
82(100 \%) \\
247(100 \%)\end{array}$ & 9,105 & $0,003^{*}$ & $\begin{array}{c}2,29 \\
(1,33-3,95)\end{array}$ \\
\hline
\end{tabular}

Keterangan:

* Bermakna ( $p<0,05$; uji chi square) 
TABEL 3. Hubungan GAKY dengan kesegaran jasmani

\begin{tabular}{|c|c|c|c|c|c|}
\hline \multirow{2}{*}{ Variabel } & \multicolumn{2}{|c|}{ Kesegaran jasmani } & \multirow{2}{*}{ Total } & \multirow{2}{*}{$\pi^{2}$} & \multirow{2}{*}{ p } \\
\hline & Baik & Kurang & & & \\
\hline $\begin{array}{l}\text { Gondok } \\
\text { Tidak gondok }\end{array}$ & $\begin{array}{l}34(47,2 \%) \\
89(50,9 \%)\end{array}$ & $\begin{array}{l}38(52,8 \%) \\
86(49,1 \%)\end{array}$ & $\begin{array}{l}72(100 \%) \\
175(100 \%)\end{array}$ & 0,270 & 0,675 \\
\hline Total & $124(50,2 \%)$ & $123(49,8 \%)$ & $247(100 \%)$ & & \\
\hline
\end{tabular}

Keterangan:

$\mathrm{p}$ (uji chi square)

Hubungan antara EYU dengan kesegaran jasmani

Metode EYU merupakan indikator yang paling dini mendeteksi terjadinya defisiensi yodium dan paling sensitif menggambarkan kecukupan yodium sehari-hari (12). Hubungan antara EYU dengan kesegaran jasmani dapat dilihat pada Tabel 4. Status EYU dikatakan kurang apabila nilai $\mathrm{EYU}<100 \mu \mathrm{g} / \mathrm{L}$ dan lebih apabila nilai EYU $>100 \mu \mathrm{g} / \mathrm{L}$. Dari tabel tersebut diketahui bahwa anak yang mempunyai nilai EYU kurang sebagian besar memiliki status kesegaran jasmani kurang, yaitu sebanyak $33(52,4 \%)$ anak. Sebaliknya, anak yang mempunyai status EYU lebih sebagian besar yaitu $93(50,5 \%)$ anak memiliki status kesegaran jasmani lebih baik. Hasil uji statistik menunjukkan bahwa tidak ada perbedaan proporsi kesegaran jasmani antara anak yang berstatus EYU kurang dengan status EYU lebih ( $p>0,05)$. EYU menggambarkan kecukupan yodium sehari, sehingga kecukupan yodium tergantung dari makanan yang dikonsumsi pada saat itu, sementara aktivitas anak SD setiap harinya cukup tinggi sehingga kesegaran jasmani anak SD tersebut tidak mempengaruhi status EYU tersebut.

\section{Hubungan antara GAKY dengan anemia}

Hubungan antara GAKY dengan anemia dapat dilihat pada Tabel 5. Dari tabel tersebut diketahui bahwa anak yang berstatus tidak gondok dan gondok sebagian besar merupakan anak anemia dengan perentase berturut-turut $68 \%$ dan $63,9 \%$. Hasil uji statistik menunjukkan bahwa tidak ada hubungan antara GAKY dengan anemia $(p>0,05)$. Hasil yang sama ditemukan pada penelitian Sihite et al. (13) bahwa tidak ada hubungan antara status anemia dengan status GAKY pada anak SD di Kabupaten Dairi dan menandakan bahwa status GAKY bukan satu-satunya faktor yang dapat mengakibatkan terjadinya anemia.

Hal ini berbeda dengan yang dikemukakan oleh Saidin (13) bahwa kekurangan zat besi bukan hanya berakibat pada berkurang atau menurunnya produksi hemoglobin, tetapi juga berdampak terhadap menurunnya kadar plasma tiroksin $\left(T_{4}\right)$ dan triiodotironin $\left(T_{3}\right)$. Hormon tiroid juga meningkatkan disosiasi oksigen dari hemoglobin dengan meningkatkan 2,3-difosfogliserat (DPG) sel darah merah. Menurut Johnson dan Currier (15), seseorang menjadi anemia disebabkan oleh beberapa faktor, antara lain: jumlah sel darah merah yang rendah, cadangan vitamin $B_{12}$ yang rendah, kekurangan zat besi, tiroid yang tidak berfungsi secara benar, kehilangan banyak darah saat haid, tingkat hormon yang rendah, dampak pengobatan atau infeksi yang menyerang sumsum tulang. Begitu pula dengan yang dikemukakan oleh Endang (16) yaitu yodium diperlukan untuk pembentukan hormon tiroksin yang diproduksi kelenjar tiroid. Yodium juga berperan dalam pembentukan sel darah merah dan protein.

TABEL 4. Hubungan EYU dengan kesegaran jasmani

\begin{tabular}{|c|c|c|c|c|c|}
\hline \multirow{2}{*}{ Status EYU } & \multicolumn{2}{|c|}{ Kesegaran jasmani } & \multirow{2}{*}{ Total } & \multirow{2}{*}{$\pi^{2}$} & \multirow{2}{*}{$\mathbf{p}$} \\
\hline & Baik & Kurang & & & \\
\hline Lebih & $93(50,5 \%)$ & $91(49,5 \%)$ & $184(100 \%)$ & 0,161 & 0,689 \\
\hline Kurang & $30(47,6 \%)$ & $33(52,4 \%)$ & $63(100 \%)$ & & \\
\hline Total & $123(49,8 \%)$ & $124(50,2 \%)$ & $247(100 \%)$ & & \\
\hline
\end{tabular}

Keterangan:

$\mathrm{p}$ (uji chi square)

TABEL 5. Hubungan GAKY dengan anemia

\begin{tabular}{|c|c|c|c|c|c|}
\hline \multirow{2}{*}{ Status GAKY } & \multicolumn{2}{|c|}{ Status hemoglobin } & \multirow{2}{*}{ Total } & \multirow{2}{*}{$\boldsymbol{x}^{2}$} & \multirow[b]{2}{*}{$\mathbf{p}$} \\
\hline & Anemia & Tidak anemia & & & \\
\hline $\begin{array}{l}\text { Tidak gondok } \\
G \text { ondok } \\
\text { Total }\end{array}$ & $\begin{array}{c}119(68,0 \%) \\
46(63,9 \%) \\
165(66,8 \%)\end{array}$ & $\begin{array}{l}56(32,0 \%) \\
26(36,1 \%) \\
82(33,2 \%)\end{array}$ & $\begin{array}{c}175(100 \%) \\
72(100 \%) \\
247(100 \%)\end{array}$ & 0,389 & 0,533 \\
\hline
\end{tabular}

Keterangan:

$\mathrm{p}$ (uji chi square) 


\section{KESIMPULAN DAN SARAN}

Dari hasil penelitian ini dapat disimpulkan bahwa menurut kriteria WHO, Kabupaten Dairi termasuk ke dalam daerah endemis ringan. Lebih jauh didapatkan adanya perbedaan status kesegaran jasmani menurut tingkat endemisitas dan adanya hubungan antara status anemia dengan kesegaran jasmani. Meskipun demikian, tidak didapatkan hubungan antara status GAKY dengan kesegaran jasmani dan antara status GAKY dengan anemia.

Dari kesimpulan di atas, disarankan agar pemerintah Kabupaten Dairi melaksanakan program penanggulangan

\section{RUJUKAN}

1. Departemen Kesehatan RI. Bantuan Teknis untuk Studi Evaluasi Proyek Intensifikasi Penanggulangan Gangguan Akibat Kekurangan Yodium (IP-GAKY) Dana Bantuan IBRD No. 4125-IND. Jakarta: Direktorat Bina Gizi Masyarakat Direktorat Jenderal Bina Kesehatan Masyarakat; 2003.

2. Lemeshow S, Hosmer D, Klar J. 1990. Adequacy of Sample Size in Health Studies. (Terjemahan) Pramono D. Yogyakarta: UGM Press; 1997.

3. Pusat Pengkajian dan Pengembangan IPTEK Olah Raga. Panduan Teknis Tes dan Latihan Kesegaran Jasmani. Jakarta: Panitia Pelaksana Seminar dan Widya Karya Nasional; 1999.

4. Biro Pusat Statistik. Data Kabupaten Dairi dalam Angka. Dairi: Biro Pusat Statistik; 2006.

5. Hairy J. Fisiologi Olahraga. Jilid I. Jakarta: Departemen Pendidikan dan Kebudayaan RI; 1989.

6. Westcott WL. Strength Training for Women. Health World [serial online] 2005 [cited 2006 Mar 5]. Available from: http://www.healthy.net/scr/ Article. asp? $\mid \mathrm{d}=322 \& \mathrm{xcntr}=1$.

7. Kartini A, WS Hertanto, Rahfiludin MZ. Kesegaran Jasmani dan Status Gizi Murid SD di Kabupaten Karanganyar Jawa Tengah. Jurnal Media Medika Indonesiana 1998;33(2):7.

8. Rosmalina Y. Gambaran Kesegaran Jasmani pada Remaja Laki-Laki dengan Anemia. Jakarta: Litbang Departemen Kesehatan Rl; 2004.
GAKY yang mengarah ke daerah endemis berat, begitu juga dengan anemia. Penyuluhan tentang pemakaian/penyimpanan garam beryodium juga penting dilakukan agar siswa mampu menyerap setiap materi yang diberikan. Khusus untuk anak sekolah, penanggulangan GAKY dan anemia dapat dilakukan melalui program Usaha Kesehatan Sekolah yang melibatkan siswa, guru, orang tua siswa, dan pedagang makanan. Program ini dapat berupa pemeriksaan kesehatan secara berkala, penyuluhan kepada warga sekolah, pengawasan terhadap makanan yang dijual di kantin sekolah, dan jika perlu ada pemberian suplemen atau makanan yang mengandung zat besi dan yodium pada siswa.

9. Susanto R, Noviat $H$, Susanto $H$, Purwanto A. Pengaruh Suplementasi Besi pada Remaja Putri Anemi terhadap Pertumbuhan dan Tingkat Kesegaran Jasmani. Ceria BKKBN [serial online] 2000 [cited 2006 Mar 4]. Available from http://ceria.bkkbn.go.id/penelitian/detail/186.

10. Susanto, Heru, Purwanto. Pengaruh Suplementasi Besi pada Remaja Putri Anemia terhadap Pertumbuhan dan Tingkat Kesegaran Jasmani [tesis]. Semarang: Fakultas Kedokteran Diponegoro; 2000.

11. Viteri FE, Torun E. Anemia and Physical Work Capacity. J Clin Hematol 1974;3:609-26.

12. Dunn JT. A Practical Guide to The Correction of lodine Defficiency. Netherland: ICCIDD; 1990.

13. Sihite GTD, Sudargo T, Adiyanti MG. Status Gangguan Akibat Kekurangan Yodium (GAKY) Anak SD pada Daerah Endemik GAKY Kabupaten Dairi Provinsi Sumatra Utara. Jurnal Gizi Klinik Indonesia 2008; 4(3): 127-133.

14. Saidin S. Dampak Suplementasi Pil Besi dan Selenium terhadap Status lodium WUS di Daerah GAKY. Jakarta: Balai Penelitian GAKY; 2007.

15. Johnson D, Currier J. Women and Anemia. The Body [serial online] 1999 [cited 2005 Jan 5]. Available from: http://www.thebody.com/content/art286.html.

16. Endang. Tumbuh Kembang Anak. Konsultasi IImiah RS Fatmawati dan Klinik Tumbuh Kembang Anak; 2003; Jakarta. 